Oleksandr Maidanyk, Yelyzaveta Meleshko, Serhii Shymko

\author{
Central Ukrainian National Technical University, Kropyvnytskyi, Ukraine
}

\title{
STUDY OF INFLUENCE OF QUADROCOPTER DESIGN AND SETTINGS ON QUALITY OF ITS WORK DURING MONITORING OF GROUND OBJECTS
}

\begin{abstract}
The subject of the article is methods of reducing quadcopter magnetometer crosstalk by changing the design and settings of the copter to improve the quality of its work during the monitoring of ground objects. The relevance of the development is determined by the need to increase the physical safety of quadcopters when monitoring ground facilities in various industries because the magnetometer is the most noise-sensitive sensor, and its failure leads to the fall and loss of the drone. The purpose of the article is to determine the optimal design and settings of the quadcopter in terms of its physical safety and quality of work during monitoring of ground facilities in various industries. The research task is to check whether it is possible to protect the magnetometer placed inside the drone body from the power cables crosstalk by grounding, shielding and changing the initial settings of the copter, namely by changing the value of the startup power factor of the motors. Research methods are as follows: theory of automatic control, methods of optimal control and hardware design methods. Conclusions. The role of the drone magnetometer in the monitoring of ground objects has been studied. The study has shown that copters at monitoring ground objects must be equipped with a magnetometer and GPS. The magnetometer is the most sensitive to interference of all sensors. If it does not work properly, the entire drone navigation system stops working. We have carried out experimental studies of the influence of quadcopter design and settings on the quality of its magnetometer work, and hence on work of the copter as a whole. In this paper it is proposed to place a magnetometer inside the body of the drone that will increase its physical safety and simplify the design of the drone, but at the same time it will increase the coupling from the power cables of motors, so it is necessary to choose effective methods of protection. It has been tested whether it is possible to protect the magnetometer from interference from power cables when placing it inside the drone body by grounding, shielding and changing the initial settings of the copter, namely by changing the value of the startup power factor of the motors. The results of the experiments showed that to protect against the interference for magnetometer placed inside the drone body, it is necessary to combine shielding of the magnetometer and decreasing of the startup power factor of the motors.
\end{abstract}

Keywords : unmanned aerial vehicle; drone, quadcopter; magnetometer; crosstalk; quality of work; monitoring of ground objects.

\section{Introduction}

An essential component of a quadcopter that monitors ground objects and is not controlled by the operator but follows a certain route is a magnetometer [1, 2], which allows navigating in the airspace and plays the role of a compass. At the same time, the magnetometer's quality and physical safety depend on the design and settings of the quadcopter. In particular, most often the magnetometer is placed in a separate module together with the GPS, which is taken outside the body of the drone and located on a special rack or top cover of the body [3]. Because of such a location, the probability of damage or loss of the magnetometer as a result of physical fractures increases, and the complexity of the design of the quadcopter rises.

This paper proposes to place a magnetometer inside the drone's body, which will increase its physical safety and simplify the drone's design. However, such placement can negatively affect the quality of the magnetometer because it is a very sensitive device [4], and its operation can be negatively affected by interference (crosstalk) from power cables of quadcopter engines [1, 4]. Therefore we conducted experimental studies of the influence of quadcopter design and settings on the quality of its magnetometer, and hence of the copter as a whole. It was checked during the experiments whether it is possible to protect the magnetometer from interference from the power supply cables by grounding, shielding and changing the initial settings of the copter.

Analysis of the literature. According to a study of the following sources [5-10], the use of unmanned aerial vehicles of the quadcopter type to monitor ground facilities in various industries is an extremely relevant task.

Use of drones in industrial monitoring. Unmanned aerial vehicles use conventional and thermal aerial photography of industrial objects from a bird's eye view. The copter transmits video and other received data to operators in real-time, then the results are sent to control points where they are analyzed and used by experts in making important decisions. This helps to react quickly and correctly in case of any emergencies. Drones effectively solve the following problems in industry [5-7]:

- operational and comprehensive control of the state of mining equipment, power lines, oil platforms and refineries, pipelines, roads and railways, construction sites and shore structures.

- continuous surveillance in hard-to-reach and dangerous places, where it is associated with a risk to human life and health.

- drones equipped with thermal imagers are used for infrared aerial photography of municipal facilities, diagnostics of the state of power lines, underground thermal networks, oil and gas pipelines. Conventional and thermal infrared aerial photography of industrial facilities allows timely detect defects and malfunctions of equipment, leaks, harmful emissions, oil slicks in areas of oil production and transportation, and other problems at the initial stage of their occurrence, without stopping production, as well as carry out search-and-rescue and security activities.

Use of drones in the monitoring of agricultural facilities. Drones in agriculture - one of the most 
promising areas, which is actively growing in demand. Technologically equipped drones in agriculture can perform various monitoring operations [8-10]:

- Aerial photography is necessary to detect crop failure and other defects that need to be eliminated in a timely manner. Aerial photography from a drone is more detailed than photography from a satellite due to the low altitude.

- Video recording - the productivity of the aircraft during video recording reaches $30 \mathrm{~km}^{2}$ per 1 hour, which significantly reduces time and financial costs compared to the use of ground surveys or piloted aircraft.

- 3D modeling - allows determining wetlands or arid areas, excavation, allows qualitatively creating plans and maps of soil humidification or drainage, of sites recultivation and land melioration.

- Thermal imaging (multispectral) imaging - is carried out using the full spectrum of infrared radiation: near, medium and far range. Exploration from the drone directly affects the yield and preservation of the productive properties of plants.

- Laser scanning - used to analyze the area in hardto-reach or inaccessible areas. It provides an exact model of high density with detailed display of a relief even when working in the strong density of plantings.

Modern copters can solve the following tasks of monitoring agricultural facilities:

- assessment of crop quality and detection of damage or death of crops;

- determining the exact area of dead crops;

- audit and inventory of lands required for the implementation of agreements;

- detection of crop defects and problematic areas;

- analysis of the effectiveness of measures aimed at plant protection;

- monitoring the compliance of the structure and plans of crop rotation;

- detection of deviations and violations committed in the process of agro-technical works;

- relief analysis and creation of a map of PVI, NDVI vegetation indices;

- gathering information for the security service, e.g., on the fact of illegal cattle grazing in the fields; systems;

- support for the construction of melioration

- monitoring of root crops storage in clamps.

Copters that monitor ground objects and are not controlled by the operator, but follow the pre-defined route, must be equipped with a magnetometer and GPS [1-3]. Operator-controlled copters must also include a magnetometer, but GPS is no longer required, in which case the compass allows for flight stability [3]. Using a magnetometer, one can determine which side of the drone is facing north [1-3] and supplement with this information the data on its location, obtained from GPS. The drone's navigation system keeps it in place against gusts of wind, the operation of intelligent modes of the drone, for example, following a certain route without an operator, including returning home in case of loss of communication.

The magnetometer is the most sensitive to interference sensor [1-4]. In addition to the fact that the natural magnetic field may be different in different flight areas, it can also be affected by extraneous magnetic fields, for example, high-voltage power lines or even from the onboard electronics of the copter itself. That is why drone assemblers often try to move the compass away from the onboard electronics, for example, on a leg that stands alone above other parts.

If the compass functions incorrectly, the whole drone navigation system stops working [4]. This means that the drone will not return home if the signal is lost, will stop flying the route, and so on.

Therefore, after reviewing the literature, it can be concluded that the magnetometer is an extremely important drone sensor, and its use is mandatory when monitoring ground objects. At the same time, it is the most noise-sensitive sensor and its placement and protection against interference is an extremely important task, the effectiveness of which depends on the quality of work and physical safety of the drone.

\section{Experiment description}

A quadcopter with the following parameters was used for the experiments: flight controller - matek f405se; engine controllers - FVT LittleBee 30A ESC BLHeli-S; magnetometer + GPS module - RadioLink TS100 M8N (it has a QMC5883L magnetometer); enginges $\mathrm{T}$ motor 2814; propellers 11/4,5 (11" diameter, 4.5" pitch). The appearance of the assembled drone is shown in Fig. 1.

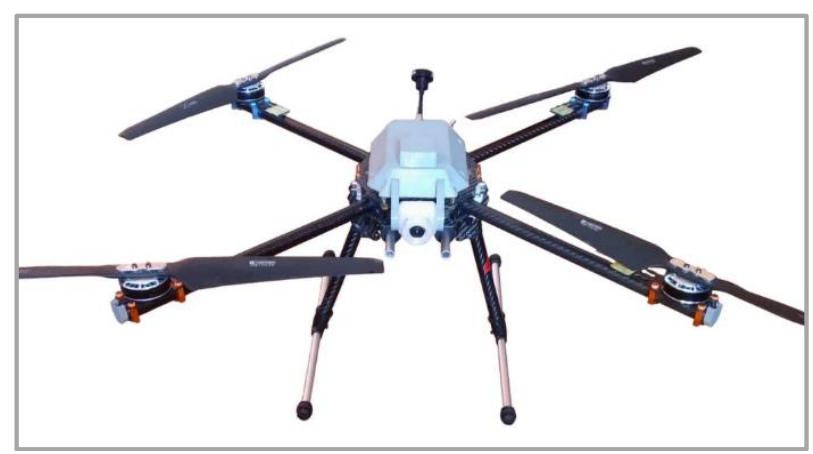

Fig. 1. Quadcopter assembled for experiments

To perform the experiment, the quadcopter was rigidly fixed to prevent it from moving when starting and supplying current to its motors, and was connected to a computer to record the values of current, interference, and throttle percentage. The task of the experiment was to determine the value of interference to the magnetometer depending on the current level. The gas was supplied in such a way as to achieve the maximum possible safe current level, but at the same time with care to not disable the power part of the drone (engine controllers and engines).

Several experiments were performed with different designs and settings of the quadcopter. During the experiments the values of interference at the quadcopter magnetometer were compared when placed it either outside the drone body or inside the body with different methods of protection against interference. The measurement results were recorded in mission planner software. ver 1.3.75 [11] (Fig. 2-6). 


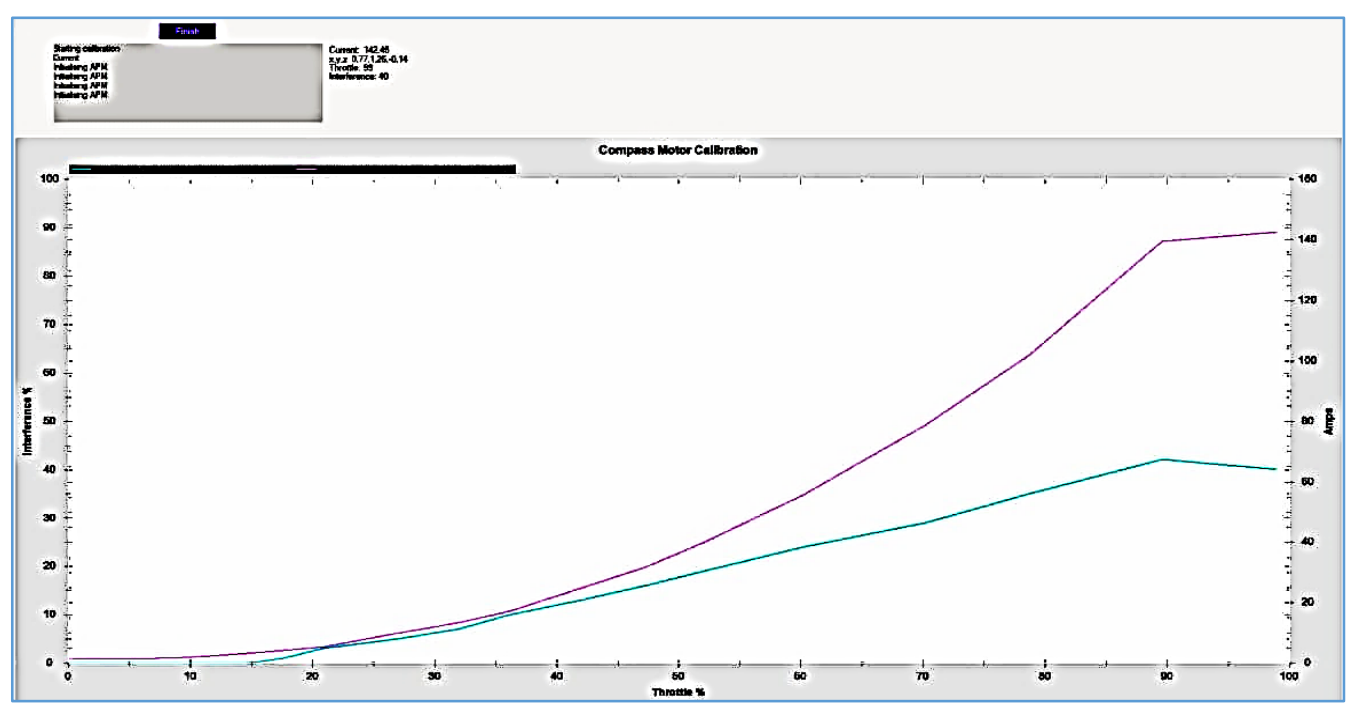

Fig. 2. Experiment No. 1. Magnetometer outside the drone body on the rack behind and without shielding (screenshot from mission planner ver 1.3.75, colors inverted): blue line - interference, pink - current

In experiment №1 (Fig. 2), the maximum interference was $40 \%$, and the maximum current was 142 A. As expected, when placing the magnetometer inside the drone body, the interference is larger - in the experiment №2, (Fig. 3) the maximum interference is $44 \%$, and the maximum current is $142 \mathrm{~A}$, although the magnetometer was shielded from electronics from the bottom, which does not shield it completely from the Earth's magnetic field. Therefore, the next step in the experiment was to determine how interference can be reduced. Therefore, experiments were performed with the grounding of the magnetometer shield (Fig. 4).

It is known that all the wire polygons can also be a source of the noise. Therefore, it was decided to connect them to the minus (ground) of the general onboard power supply. In experiment № 3 (Fig. 4), the shielding of the magnetometer was grounded, and the following results were obtained: maximum interference - 44\%, and maximum current $75 \mathrm{~A}$. As one can see from the results of the experiment, grounding did not reduce the interference. Subsequent experiments were designated to reduce the startup power factor of quadcopter motors from 0.5 to 0.1 (Fig. 5) and to 0.2 (Fig. 6), that gave the necessary result and solved the interference problem. In experiment № 3 (Fig. 4), the shielding of the magnetometer was grounded, and the following results were obtained: maximum interference - 44\%, and maximum current $75 \mathrm{~A}$. As one can see from the results of the experiment, grounding did not reduce the interference. Subsequent experiments were designated to reduce the startup power factor of quadcopter motors from 0.5 to 0.1 (Fig. 5) and to 0.2 (Fig. 6), that gave the necessary result and solved the interference problem.

In experiment № 3 (Fig. 4), the shielding of the magnetometer was grounded, and the following results were obtained: maximum interference $-44 \%$, and maximum current $75 \mathrm{~A}$. As one can see from the results of the experiment, grounding did not reduce the interference. Subsequent experiments were designated to reduce the startup power factor of quadcopter motors from 0.5 to 0.1 (Fig. 5) and to 0.2 (Fig. 6), that gave the necessary result and solved the interference problem.

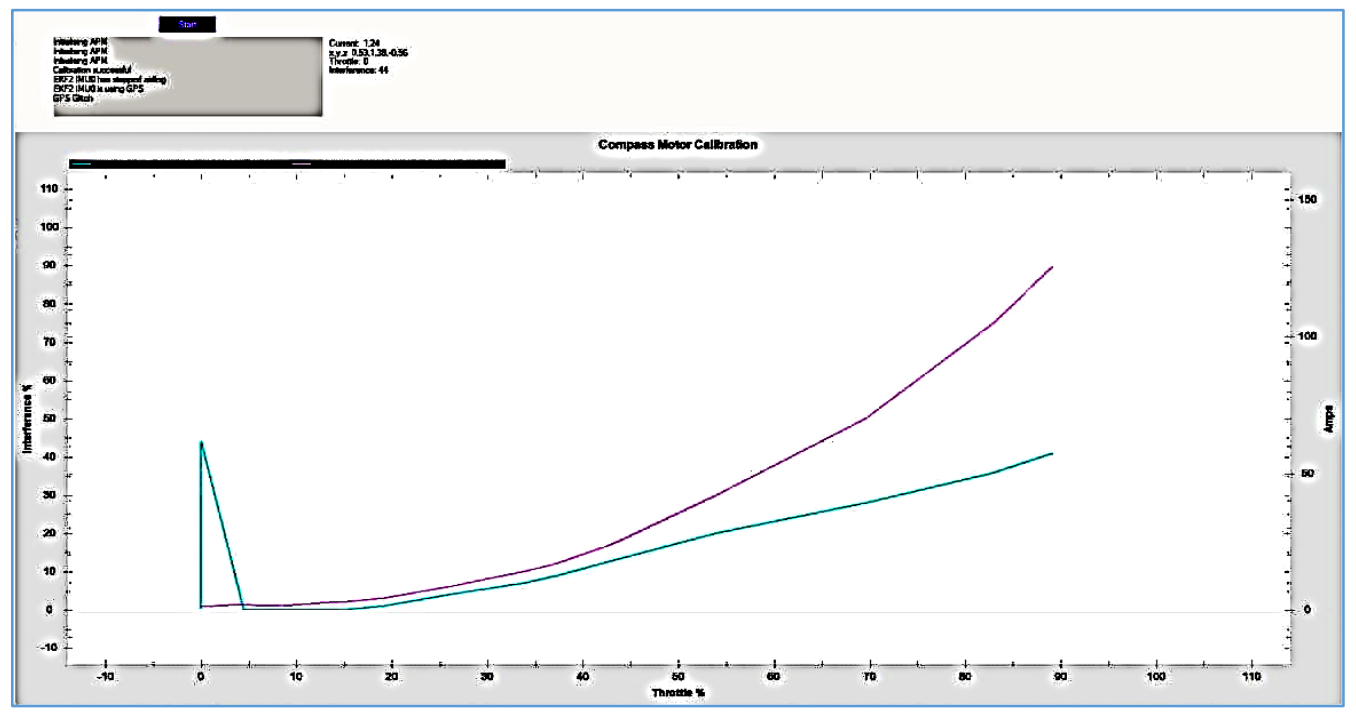

Fig. 3. Exp. № 2. Magnetometer inside the drone body at the top of the flight controller, shielded (screenshot from mission planner ver 1.3.75, colors inverted): blue line - interference, pink - current 


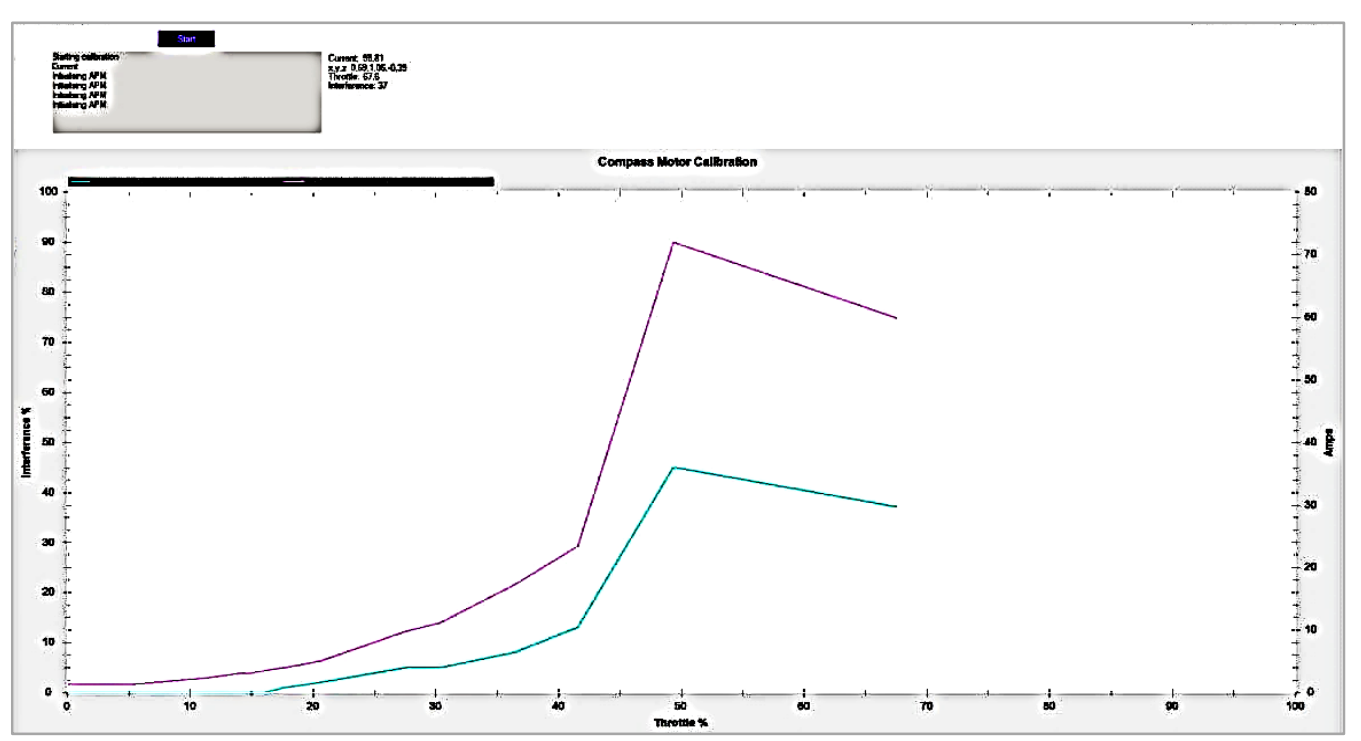

Fig. 4. Exp. № 3. Magnetometer inside the drone body, above the flight controller, shielded, grounded (screenshot from mission planner ver 1.3.75, colors inverted): blue line - interference, pink - current

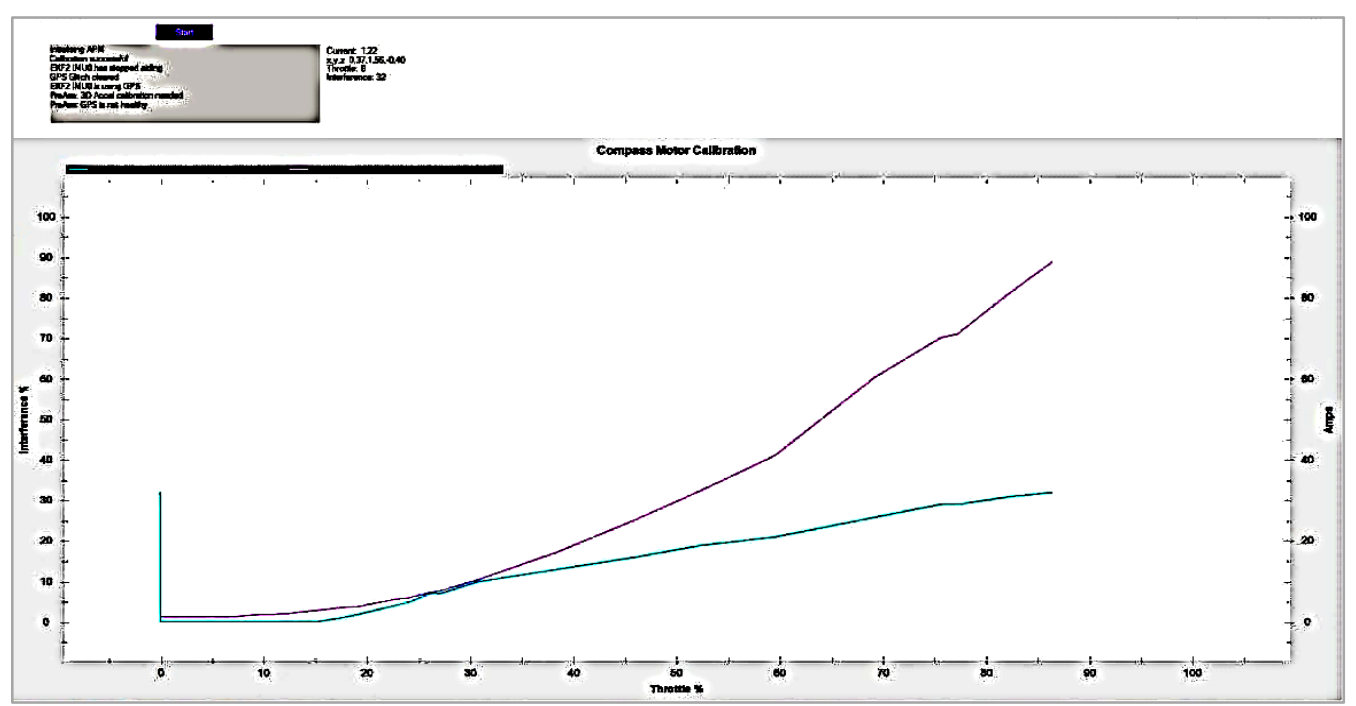

Fig. 5. Exp. № 4. Magnetometer inside the drone body, above the flight controller, shielded, grounded shield, reduced engine startup power factor from 0.5 to 0.1 (screenshot from mission planner ver 1.3.75, inverted colors): blue line - interference, pink - current

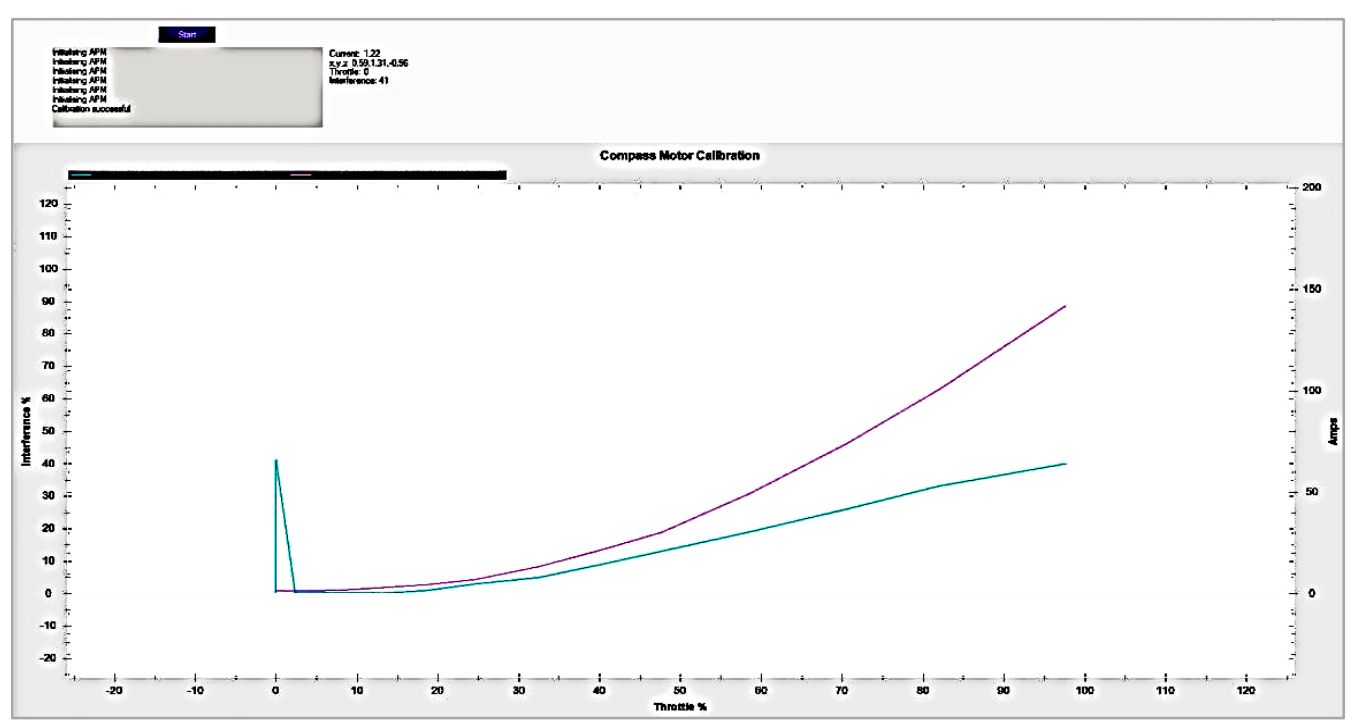

Fig. 6. Exp. № 5. Magnetometer inside the drone body, above the flight controller, shielded, grounded shield, startup power factor 0.2 (screenshot from mission planner ver 1.3.75, inverted colors): blue line - interference, pink - current 
Note that the startup power factor adjusts how quickly the speed controller responds to rapid changes in gas supply [12]. Shielding of the magnetometer was performed using a plate of foil fiberglass with a thin copper layer. The GPS + magnetometer module itself was located above the flight controller in the drone body.

The results of experiment №4 (Fig. 5) were as follows: the maximum guidance is $32 \%$, and the maximum current is $88 \mathrm{~A}$.

Although the lowest interference values were achieved amongst all the experiments, it should be noted that with this value of the coefficient, the good result for the interference was achieved, but the smaller the value of this factor, the worse the dynamics of the engines is, so the optimum between this parameter and the magnitude of the interference should be searched. In Fig. 6 the results of experiment №5 are shown, where the startup power factor is set to 0.2 , the value of the interference has increased slightly, but is practically no worse than when the magnetometer is removed from the body. Experimental results here are as follows: the maximum guidance is $41 \%$, and the maximum current is 149A.

\section{Conclusions}

The role of the drone magnetometer during the monitoring of ground objects has been studied. The research has shown that copters that monitor ground objects and are not controlled by the operator but follow the pre-defined route, must be equipped with a magnetometer and GPS. The magnetometer is the most sensitive to the interference sensor. If it does not work correctly, the entire drone navigation system stops working.

We carried out experimental studies on the influence of quadcopter design and settings on the quality of its magnetometer, and hence the copter as a whole. Most often, the magnetometer is placed in a separate module together with the GPS, which is placed outside the drone body and located on a special stand behind the body rack or top cover of the body. As a result of such placement the probability of damage or loss of the magnetometer as a result of physical breakdowns increases as well as complexity of a quadcopter design. In this paper it is proposed to place a magnetometer inside the drone body, which will increase its physical safety and simplify the design of the drone. It has been tested whether the magnetometer can be protected when placed inside the drone body from grounding from the power cable, shielding from the main electronics and changing the starting settings of the helicopter, namely by changing the value of the startup power factor of the motors.

The results of the experiments showed that to protect the magnetometer from the interference if it is placed inside the drone body, it is necessary to combine shielding of the magnetometer and decreasing of the startup power factor of the motors. Moreover, the reduction of the startup power factor of the engines from 0.5 to 0.1 for the drone used in the experiment gave the greatest effect. And the optimal result for the balance between the amount of guidance and the quality of the dynamics of the engines was the value of startup power factor of the engines equals 0.2 , for the drone used in the experiment.

\section{REFERENCES}

1. (2021), Advanced Compass Setup, available at: https://ardupilot.org/copter/docs/common-compass-setup-advanced.html?highlight

2. Shtaev, D.V. (2019), “Analysis of control technology for unmanned aerial vehicles”, Territory of new opportunities, №2, available at: $\mathrm{https://cyberleninka.ru/article/n/analiz-tehnologii-upravleniya-bespilotnymi-letatelnymi-apparatami} \mathrm{(in} \mathrm{Russian)}$

3. (2021), DIY drone: Flight controller, available at: https://www.djimsk.ru/guides/2018/05/25/drone-crash/ (in Russian)

4. (2018), Top 10 reasons for a drop of a quadrocopters, Website of the Company "DJI Authorized Retail Store", DJI Buyer's guide, available at: https:/www.djimsk.ru/guides/2018/05/25/drone-crash/ (in Russian)

5. (2020), Industrial Monitoring: Drone to Help!, Website of the Company "DRONARIUM", aerial filming and drone services, available at: https://www.dronarium.com.ua/uslugi/promyshlennyj-monitoring/ (in Russian)

6. Minin, I.V. (2015), "Anti-fire monitoring of petrochemical facilities with small autonomous unmanned aerial vehicles", Fundamental research. № 10-3. C. 503-506, available at: https://fundamental-research.ru/ru/article/view?id=39245 (in Russian)

7. Agarwal A., Shukla V., Singh R., Gehlot A. and Garg V. (2018), "Design and Development of Air and Water Pollution Quality Monitoring Using IoT and Quadcopter", In: Singh R., Choudhury S., Gehlot A. (eds) Intelligent Comm., Control and Devices, Advances in Intelligent Systems and Computing, Vol. 624, Springer, DOI: https://doi.org/10.1007/978-981-10-5903-2 49

8. (2019), Unmanned aerial vehicles in agriculture, Website of the Company "GEOMIR", Modern technologies for agribusiness, available at: https://www.geomir.ru/publikatsii/bespilotniki-v-selskom-khozyaystve/ (in Russian)

9. Duggal, V., Sukhwani, M., Bipin, K., Reddy, G.S. and Krishna, K.M. (2016), "Plantation monitoring and yield estimation using autonomous quadcopter for precision agriculture", IEEE Int. Conf. ICRA, pp. 5121-5127, doi: 10.1109/ICRA.2016.7487716

10. Zubarev, Ju.N., Fomin, D.S., Chashhin ,A.N. and Zabolotnova, M.V. (2019), "The use of unmanned aerial vehicles in agriculture”, Bulletin of the Perm Federal Research Center, №2. available at: https://cyberleninka.ru/article/n/ispolzovaniebespilotnyh-letatelnyh-apparatov-v-selskom-hozyai-stve (in Russian)

11. (2021), Mission Planner Home, ArduPilot Documentation, available at: https://ardupilot.org/planner/index.html

12. (2017), How to configure your BLHeli ESCs, available at: https://www.propwashed.com/configure-blheli-escs/

Received (Надійшла) 22.09.2021

Accepted for publication (Прийнята до друку) 03.11.2021

\section{ВідОмОсті ПРО АВтоРіВ/ АвоUT тHE AUTHORS}

Майданик Олександр Олександрович - магістрант кафедри кібербезпеки та програмного забезпечення, Центральноукраїнський національний технічний університет, Кропивницький, Україна;

Oleksandr Maidanyk - Master's student of Cybersecurity and Software Department, Central Ukrainian National Technical University, Kropyvnytskyi, Ukraine;

e-mail: maidanyksmail@gmail.com; ORCID ID: https://orcid.org/0000-0002-8580-7502. 
Мелешко Слизавета Владиславівна - доктор технічних наук, доцент, доцент кафедри кібербезпеки та програмного забезпечення, Центральноукраїнський національний технічний університет, Кропивницький, Україна;

Yelyzaveta Meleshko - Doctor of Engineering Sciences, Associate Professor, Associate Professor of Cybersecurity and Software Department, Central Ukrainian National Technical University, Kropyvnytskyi, Ukraine;

e-mail: elismeleshko@ gmail.com; ORCID ID: https://orcid.org/0000-0001-8791-0063.

Шимко Сергій Вікторович - аспірант кафедри кібербезпеки та програмного забезпечення, Центральноукраїнський національний технічний університет, Кропивницький, Україна;

Serhii Shymko - Postgraduate student of Cybersecurity and Software Department, Central Ukrainian National Technical University, Kropyvnytskyi, Ukraine;

e-mail: shymko.sv@ meta.ua; ORCID ID: https://orcid.org/0000-0002-1132-484X.

\title{
Дослідження впливу конструкції та налаштувань квадрокоптера на якість його роботи при моніторингу наземних об'єктів
}

\author{
О. О. Майданик, Є. В. Мелешко, С. В. Шимко
}

Анотація. Предметом вивчення у статті є методи зменшення наведень на магнітометр квадрокоптера за рахунок зміни конструкції та налаштувань коптера для підвищення якості його роботи при моніторингу наземних об'єктів. Актуальність розробки визначається необхідністю підвищення фізичної безпеки квадрокоптерів при моніторингу наземних об'єктів у різних галузях виробництва, адже, магнітометр є найбільш чутливим до шумів датчиком, а його вихід 3 ладу призводить до падіння та втрати дрону. Метою $є$ визначення оптимальної конструкції та налаштувань квадрокоптера $з$ точки зору його фізичної безпеки та якості роботи при моніторингу наземних об'єктів у різних галузях виробництва. Завдання: перевірити чи можна захистити магнітометр при розміщенні його всередині корпусу дрону від завад 3 кабелів електроживлення заземленням, екрануванням та зміною стартових налаштувань коптера, а саме зміною значення коефіцієнту пускової потужності двигунів. Методи досліджень: теорія автоматичного управління, методи оптимального управління та методи проектування апаратного забезпечення. Висновки. Проведено дослідження ролі магнітометра дрону при моніторингу наземних об'єктів. Дослідження показало, що коптери, які здійснюють моніторинг наземних об'єктів, обов'язково повинні бути оснащені магнітометром та GPS. Магнітомер найбільш чутливий до перешкод датчик. Якщо він працює неправильно, перестає працювати вся навігаційна система дрону. Проведено експериментальні дослідження по впливу конструкції та налаштувань квадрокоптера на якість роботи його магнітометра, а одже і коптера в цілому. У даній роботі запропоновано розмістити магнітометр всередині корпусу дрона, що підвищить його фізичну безпеку та спростить конструкцію дрону, але разом з тим на нього збільшуються завади від кабелів електроживлення двигунів, тому необхідно підібрати ефективні методи захисту від таких завад. Перевірено чи можна захистити магнітометр при розміщенні його всередині корпусу дрону від завад з кабелів електроживлення заземленням, екрануванням та зміною стартових налаштувань коптера, а саме зміною значення коефіцієнту пускової потужності двигунів. Результати проведених експериментів показали, що для захисту від завад магнітометра, розміщеного всередині корпусу дрона, необхідно поєднати екранування магнітометра та зменшення коефіцієнту пускової потужності моторів.

Ключові слов а : безпілотний літальний апарат; дрон; квадрокоптер; магнітометр; наведення; якість роботи; моніторинг наземних об'єктів.

\section{Исследование влияния конструкции и настроек квадрокоптера на качество его работы при мониторинге наземных объектов}

\section{А. А. Майданик, Е. В. Мелешко, С. В. Шимко}

Ан нотация. Предметом изучения в статье являются методы уменьшения наводок на магнитометр квадрокоптера за счет изменения конструкции и настроек коптера для повышения качества его работы при мониторинге наземных объектов. Актуальность разработки определяется необходимостью повышения физической безопасности квадрокоптеров при мониторинге наземных объектов в различных отраслях производства, ведь магнитометр является наиболее чувствительным к шумам датчиком, а его выход из строя приводит к падению и потере дрона. Целью является определение оптимальной конструкции и настроек квадрокоптера с точки зрения его физической безопасности и качества работы при мониторинге наземных объектов в различных отраслях производства. Задача: проверить, можно ли защитить магнитометр при размещении его внутри корпуса дрона от наводок от кабеля электропитания заземлением экранированием и изменением стартовых настроек коптера, а именно изменением значения коэффициента пусковой мощности двигателей. Методы исследований: теория автоматического управления, методы оптимального управления и методы проектирования аппаратного обеспечения. Выводы. Проведено исследование роли магнитометра дрона при мониторинге наземных объектов. Исследование показало, что коптеры, производящие мониторинг наземных объектов, обязательно должны быть оснащены магнитометром и GPS. Магнитомер наиболее чувствительный к помехам датчик. Если работает неправильно, перестает работать вся навигационная система дрона. Проведены экспериментальные исследования по влиянию конструкции и настройкам квадрокоптера на качество работы его магнитометра, а значит и коптера в целом. В данной работе предложено разместить магнитометр внутри корпуса дрона, что повысит его физическую безопасность и упростит конструкцию дрона, но вместе с тем на него увеличиваются наводки от кабелей электропитания, поэтому необходимо подобрать эффективные методы защиты от таких наводок. Проверено можно ли защитить магнитометр при размещении его внутри корпуса дрона от наводок из кабеля электропитания заземлением, экранированием и изменением стартовых настроек коптера, а именно изменением значения коэффициента пусковой мощности двигателей. Результаты проведенных экспериментов показали, что для защиты от наводок магнитометра, размещённого внутри корпуса дрона, необходимо объединить экранирование магнитометра с уменьшением коэффициента пусковой мощности моторов.

Ключевые слова: беспилотный летательный аппарат4 дрон; квадрокоптер; магнитометр; наводки; качество работы; мониторинг наземных объектов. 